\title{
A new genus of Norian involutinid foraminifer: Its morphological, biostratigraphic and evolutionary significance
}

Sylvain Rigaud, Rossana Martini, and Roberto Rettori

Acta Palaeontologica Polonica 58 (2), 2013: 391-405 doi: http://dx.doi.org/10.4202/app.2011.0072

The Late Triassic was a time of pronounced radiation in several groups of foraminifers. The rapid evolutionary processes in the Suborder Involutinina caused particularly high diversification of these aragonitic foraminifers, which became a key group for Upper Triassic biostratigraphy. Among them, Triasina hantkeni and Triasina oberhauseri are regarded as the most precise guide fossils. However, while these species are widely used, a poor documentation of the detailed test structure of T. oberhauseri has resulted in misidentifications. The exceptional preservation and abundance of Triasina oberhauseri in the Upper Triassic deposits of the Black Marble Quarry (Wallowa terrane, Oregon, USA) has allowed us to make the first detailed observations of its coiling, innermost structure and lamellae arrangement and to recognize morphological features that were either wrongly interpreted or not described in the original systematic definition of the species. In this paper, we demonstrate that the species possesses characteristics that hamper its assignment to Triasina and we propose a new genus, Aulosina, to accommodate this taxon. Placing emphasis on the accuracy of the morphological description, the diagnosis and the systematic definition of the species are here improved. The identification of innovative features in Aulosina oberhauseri (strengthenings, shortened lamellae) highlights new evolutionary trends for the lineage of Involutinina that have proved useful for the establishment of phylogenetic links between involutinid genera and for understanding the evolutive steps leading to the formation of inner-pillars in tubular foraminifers. The increasing complexity of Involutinina representatives at the end of the Triassic, notably marked by the appearance of internal structures in Triasininae, leads us to regard them as probable symbiont-bearing foraminifers.

Key words: Foraminifera, strengthening, shortened lamellae, symbiosis, Triassic, Wallowa terrane, Oregon, USA.

Sylvain Rigaud [Sylvain.Rigaud@unige.ch] and Rossana Martini [Rossana.Martini@unige.ch ], Département de géologie et paléontologie, 13 rue des Maraîchers, 1205 Genève, Switzerland; Roberto Rettori [rrettori@unipg.it], Dipartimento di Scienze della Terra, Piazza Università, 06123 Perugia, Italy. 
This is an open-access article distributed under the terms of the Creative Commons Attribution License (for details please see creativecommons.org), which permits unrestricted use, distribution, and reproduction in any medium, provided the original author and source are credited.

For Full text $(1,316.1 \mathrm{kB})$ 